\title{
Effect of storage temperature on the quality of eggs from conjugated linoleic acid-fed laying hens
}

\author{
R. Aydin \\ Department of Animal Science, Kahramanmaras Sutcu Imam University, 46060 Kahramanmaras-Turkey
}

\begin{abstract}
This study was designed to investigate the effects of storage temperature on the quality of eggs from conjugated linoleic acid (CLA)-fed laying hens. For 40 days laying hens (20 per group) were fed a diet containing either $0.5 \%$ maize oil (Group A, Control) or $0.5 \%$ CLA (Group B). For fatty acid analysis, three eggs were collected after the eighth day of feeding. After two days of feeding, eggs were collected and stored for 28 days at $4{ }^{\circ} \mathrm{C}, 15^{\circ} \mathrm{C}$ or $24{ }^{\circ} \mathrm{C}$ for colour quality assessment. For $\mathrm{pH}$ measurements, 30 eggs from each group were stored at $4{ }^{\circ} \mathrm{C}$ or room temperature $\left(21-24{ }^{\circ} \mathrm{C}\right)$ for one, two or three weeks. Dietary CLA caused higher levels of $\mathrm{C} 16: 0$ and $\mathrm{C} 18: 0$ and lower levels of $\mathrm{C} 16: 1(\mathrm{n}-7)$ and $\mathrm{C} 18: 1(\mathrm{n}-9)$ compared to the control group. Egg yolk from Group B had higher levels of c-9, t-11 and t-10, c-12 CLA than the control group. The ratio of total saturated to unsaturated fatty acids (SFA/UFA) increased 2.4-fold in the eggs from CLA-fed hens. CLA eggs stored at $4{ }^{\circ} \mathrm{C}$ had higher $\mathrm{pH}$ values in yolk and lower $\mathrm{pH}$ values in albumen compared to those from the control group. However, $\mathrm{pH}$ values of yolk or albumen in eggs stored at $21-24{ }^{\circ} \mathrm{C}$ were similar in the control and treatment groups. Dietary CLA caused significant colour changes in yolk and albumen of the eggs stored at $4{ }^{\circ} \mathrm{C}$ and $15^{\circ} \mathrm{C}$. No colour changes were observed in the yolk and albumen of CLA eggs at $21-24^{\circ} \mathrm{C}$. Results indicated that dietary CLA influenced fatty acid composition of eggs and had negative effects on the quality of eggs stored at $4{ }^{\circ} \mathrm{C}$ or $15{ }^{\circ} \mathrm{C}$, but not at room temperature $\left(21-24{ }^{\circ} \mathrm{C}\right)$. It is suggested that CLA probably changed the permeability of the vitelline membrane during cold storage.
\end{abstract}

Keywords: Conjugated linoleic acid, ratio of SFA/UFA, storage temperature, egg quality E-mail: rahimaydin@ksu.edu.tr

\section{Introduction}

Conjugated linoleic acid, briefly known as CLA, is a mixture of geometrical and positional isomers of linoleic acid (C18:2 c-9, c-12) and involves a double bond at positions 8 and 10, 9 and 11, 10 and 12 or 11 and 13 (Eulitz et al., 1999). Each of these positional conjugated diene isomers can occur in cis-trans, transcis, cis-cis or trans-trans geometrical configurations. Originally isolated from grilled ground beef, CLA occurs naturally in meat and dairy products from ruminant animals (Ha et al., 1990; Chin et al., 1992). The chicken egg contains little or no CLA (Chin et al., 1992).

Since dietary CLA has some biological properties such as anticarcinogenic (Ip et al., 1994), antiatherogenic (Lee et al., 1994; Nicolosi et al., 1997) and immune inducing activities (Cook et al., 1993), enhancing the CLA concentration of egg, milk and meat is of interest. The accumulation of CLA in these products is dose and time dependent. Chicken eggs were shown to be enriched with CLA (Chamruspollert \& Sell, 1999; Du et al., 1999; Raes et al., 2002; Sun et al., 2003). By feeding laying hens 5\% CLA in the diet, an egg could be enriched in CLA as high as $11 \%$ (Chamruspollert \& Sell, 1999). However, dietary CLA was reported to cause hardening of egg yolk and discoloration in the yolk and albumen of eggs stored at $4{ }^{\circ} \mathrm{C}$ (Aydin et al., 2001). Dietary CLA influences the fatty acid composition of egg yolk in a dose and timedependent manner (Aydin \& Cook, 2004). Dietary CLA was also reported to increase the firmness of hardcooked egg yolk (Ahn et al., 1999). In a previous study, it was shown that eggs from CLA-fed hens (stored at $4{ }^{\circ} \mathrm{C}$ for 10 weeks) had higher iron, calcium and zinc concentrations and lower magnesium, sodium and chloride concentrations in albumen relative to those from laying hens fed maize oil (Aydin et al., 2001). A recent study showed that sodium, potassium and magnesium concentration of the egg yolk increased as the CLA levels increased in a diet (Shang et al., 2004). The textural changes in the eggs from CLA-fed laying hens could be related to an increase of yolk water content, the movement of ions between yolk and albumen or change of egg yolk pH during cold storage (Ahn et al., 1999). When CLA eggs were stored at $4{ }^{\circ} \mathrm{C}$ for 10 weeks, abnormal pH changes were observed in the egg yolk and albumen (Aydin et al., 2001). It can be 
speculated that CLA increases the saturated fatty acids (SFA) concentration of the vitelline membrane so that, during cold storage, the vitelline membrane is disrupted, causing leakage of minerals and water from the egg albumen into the yolk. Recently, Watkins et al. (2003) showed that the level of C18:0 in the vitelline membrane was increased by dietary CLA. A preliminary study showed that when eggs from CLA-fed laying hens were stored at a warmer room temperature, no abnormal colour and $\mathrm{pH}$ changes were observed in the yolk and albumen compared to the control group (R. Aydin, unpublished data). Therefore, the objective of this study was to evaluate the effects of storage temperature on the quality of the eggs from laying hens fed CLA.

\section{Materials and Methods}

Forty 28-week old Single Comb White Leghorn (SCWL) laying hens were assigned randomly into two groups of 20 hens per group. The hens were kept in individual cages and each hen was considered an experimental unit. They were fed for 40 days on a diet containing either $0.5 \%$ maize oil (Group A, control) or $0.5 \%$ CLA (Group B). Both diets contained $150 \mathrm{~g}$ crude protein and $11.7 \mathrm{MJ}$ metabolisable energy $/ \mathrm{kg}$. The ingredient composition of the diets is presented in Table 1 . The commercial source of CLA contained $80 \%$ CLA and consisted of $35.33 \%$ c- 9 , t- 11 and t-9, c- $11 ; 35 ; 72 \%$ t-10, c- $12 ; 1.11 \%$ c- 9 , c- $11 ; 1.57 \%$ c- 10 , $\mathrm{c}-12 ; 0.91 \% \mathrm{t}-9, \mathrm{t}-11$ and $\mathrm{t}-10, \mathrm{t}-12$ CLA isomers. Other fatty acids in CLA were $6.64 \%$ palmitate, $2.39 \%$ stearate, $13.77 \%$ oleate, $0.81 \%$ linoleate and $1.75 \%$ unknown.

For fatty acid analysis, three eggs from each dietary group were collected on the $8^{\text {th }}$ day of feeding. A previous study showed that dietary CLA inclusion of $0.5 \%$ could completely modify the fatty acid composition of eggs after 6-8 days of feeding laying hens (Aydin et al., 2001). Egg content was separated into yolk and albumen, and the yolk was stored at $-20{ }^{\circ} \mathrm{C}$ pending fatty acid analysis. The fat from the egg yolk was extracted with chloroform : methanol (2:1 v/v) (Folch et al., 1957). Fatty acid methyl esters (FAME) were prepared by reaction with $4 \% \mathrm{HCL}$ in methanol for $20 \mathrm{~min}$ at $60{ }^{\circ} \mathrm{C}$, and the composition of FAME was determined by gas chromatography (Hewlett-Packard 5890). Heptadecanoic acid (C17:0) was used as an internal standard.

Table 1 Ingredients of experimental diets ${ }^{1}$ supplemented with $0.5 \%$ maize oil or $0.5 \%$ CLA

\begin{tabular}{|c|c|c|}
\hline \multirow[t]{2}{*}{ Ingredients } & $\begin{array}{c}\text { Group A } \\
\text { (Basal diet with maize oil) }\end{array}$ & $\begin{array}{c}\text { Group B } \\
\text { (Basal diet with CLA) }\end{array}$ \\
\hline & \multicolumn{2}{|c|}{$\mathrm{g} / 100 \mathrm{~g}$ diet } \\
\hline Maize grain & 67.99 & 67.99 \\
\hline Soyabean meal ( $44 \% \mathrm{CP})$ & 20.39 & 20.39 \\
\hline Calcium carbonate & 8.34 & 8.34 \\
\hline Dicalcium phosphate & 1.21 & 1.21 \\
\hline DL-Methionine & 0.07 & 0.07 \\
\hline Maize oil & 0.5 & 0 \\
\hline CLA & 0 & 0.5 \\
\hline Salt & 0.5 & 0.5 \\
\hline Vitamin/mineral premix ${ }^{2}$ & 1.0 & 1.0 \\
\hline
\end{tabular}

\footnotetext{
${ }^{1} \overline{\text { Diets were isonitrogenous and isoenergetic and calculated to contain } 150 \mathrm{~g} \text { crude protein }(\mathrm{CP}) / \mathrm{kg} \text { and }}$ 11.7 MJ metabolisable energy $/ \mathrm{kg}$

${ }^{2}$ Supplied/kg of diet: Vitamin A - 10,000 IU; vitamin $\mathrm{D}_{3}-9790 \mathrm{IU}$; vitamin E - $121 \mathrm{IU}$; vitamin $\mathrm{B}_{12}-20 \mu \mathrm{g}$; riboflavin - $4.4 \mathrm{mg}$; calcium panthothenate - $40 \mathrm{mg}$; niacin - $22 \mathrm{mg}$; choline - $840 \mathrm{mg}$; biotin - 30 $\mu \mathrm{g}$; thiamine $4 \mathrm{mg}$; zinc sulphate - $60 \mathrm{mg}$; manganese oxide - $60 \mathrm{mg}$
}

Eggs were examined for interior and exterior quality. Egg quality was assessed by measuring $\mathrm{pH}$ and yolk colour of eggs stored at cold or warm temperatures. For the measurements of egg yolk and albumen $\mathrm{pH}$, 30 eggs per group were stored at $4{ }^{\circ} \mathrm{C}$ or $24{ }^{\circ} \mathrm{C}$ for one, two or three weeks (five eggs per each storage temperature and week duration). After noting any observable discoloration in the eggs, the albumen and yolk 
samples were stirred separately with a glass rod during $\mathrm{pH}$ measurements. Tristimulus colour coordinates $\left(\mathrm{L}^{*}, \mathrm{a}^{*}, \mathrm{~b}^{*}\right)$ were recorded on the yolk of the eggs stored for 28 days at $4{ }^{\circ} \mathrm{C}, 15{ }^{\circ} \mathrm{C}$ or at room temperature (21-24 ${ }^{\circ} \mathrm{C}$ ), using a chromameter (CR-300; Minolta Cameras, Osaka, Japan). The instrument was calibrated, using a white calibration plate (Calibration Plate CR-A43, Minolta Cameras) at the beginning of each session. Thirty eggs per group were collected during the last week of the study and were stored at $4{ }^{\circ} \mathrm{C}$ for 30 days. They were then weighed, broken open, and the albumen, yolk and shell were separated and weighed.

Data for fatty acid analysis, egg parameters, and yolk and albumen $\mathrm{pH}$ of eggs were analyzed using the general linear models procedure of SPSS, version 10.0 (SPSS Inc. Chicago, USA). The statistical models included the main effects of diet and temperature. Means were considered to be statistically significantly different at $\mathrm{P}<0.05$.

\section{Results}

The effect of diets supplemented with $0.5 \%$ maize oil or $0.5 \%$ CLA on the fatty acid composition of egg yolk is presented in Table 2. Dietary CLA increased the level of SFA (C16:0 and C18:0) and decreased the levels of monounsaturated fatty acids (MUFA; C16:1, n-7 and C18:1, n-9) in the egg yolk. The ratios of C16:0/C16:1(n-7) and C18:0/C18:1(n-9) increased approximately 2.8 and 3.8-fold, respectively, in eggs from the CLA-fed hens compared to the control group. The level of c-9, t-11 CLA isomer was increased 10fold in eggs from the CLA-fed hens compared to the control group. The isomer, t-10, c-12 CLA, was not detectable in the fat of the control eggs, but fat in eggs from CLA-fed hens contained $0.52 \%$. Dietary CLA decreased the ratio of unsaturated fatty acids/saturated fatty acids (UFA/SFA) significantly in the eggs compared to those from Group A.

Table 2 Fatty acid composition (mean \pm s.e.) in egg yolk from laying hens fed diets containing $0.5 \%$ maize oil or $0.5 \%$ conjugated linoleic acid (CLA) ${ }^{1}$

\begin{tabular}{|c|c|c|}
\hline \multirow[b]{2}{*}{ Fatty Acid } & \multicolumn{2}{|c|}{$\%$ of Total fatty acids } \\
\hline & $\begin{array}{c}\text { Group A } \\
\text { (Basal diet with maize oil) }\end{array}$ & $\begin{array}{c}\text { Group B } \\
\text { (Basal diet with CLA) }\end{array}$ \\
\hline C10:0 & $0.06 \pm 0.01$ & $0.05 \pm 0.01$ \\
\hline $\mathrm{C} 12: 0$ & $0.10 \pm 0.02$ & $0.10 \pm 0.02$ \\
\hline C14:0 & $0.61^{\mathrm{b}} \pm 0.01$ & $1.02^{\mathrm{a}} \pm 0.01$ \\
\hline C16:0 & $29.65^{b} \pm 1.02$ & $40.64^{\mathrm{a}} \pm 2.01$ \\
\hline $\mathrm{C} 16: 1(\mathrm{n}-7)$ & $4.11^{\mathrm{a}} \pm 0.21$ & $1.99^{b} \pm 0.06$ \\
\hline $\mathrm{C} 18: 0$ & $8.50^{b} \pm 0.25$ & $17.61^{\mathrm{a}} \pm 1.02$ \\
\hline C18:1(n-9) & $40.24^{\mathrm{a}} \pm 0.62$ & $22.23^{b} \pm 0.15$ \\
\hline C18:2(n-6) & $14.62 \pm 0.09$ & $13.07 \pm 1.06$ \\
\hline$\alpha \mathrm{C} 18: 3(\mathrm{n}-3)$ & $0.15 \pm 0.01$ & $0.14 \pm 0.01$ \\
\hline$\gamma \mathrm{C} 18: 3(\mathrm{n}-6)$ & $0.54 \pm 0.01$ & $0.38 \pm 0.00$ \\
\hline $\mathrm{C} 20: 4(\mathrm{n}-6)$ & $1.29 \pm 0.02$ & $0.95 \pm 0.03$ \\
\hline c- $9, \mathrm{t}-11$ CLA & $0.13^{b} \pm 0.00$ & $1.30^{\mathrm{a}} \pm 0.01$ \\
\hline $\mathrm{t}-10, \mathrm{c}-12$ CLA & n.d. & $0.52 \pm 0.03$ \\
\hline$\Sigma$ SFA & $38.92^{b} \pm 1.23$ & $59.42^{\mathrm{a}} \pm 1.73$ \\
\hline ¿MUFA & $44.35^{\mathrm{a}} \pm 1.35$ & $24.22^{b} \pm 0.08$ \\
\hline$\Sigma$ PUFA & $16.60 \pm 0.09$ & $14.54 \pm 1.47$ \\
\hline$\Sigma$ UFA & $60.95^{\mathrm{a}} \pm 1.22$ & $38.76^{\mathrm{b}} \pm 1.95$ \\
\hline
\end{tabular}

${ }^{1}$ For fatty acid content analysis, the eggs were obtained on the $8^{\text {th }}$ day of feeding experimental diets

a, b, c Means (three egg yolks per treatment) without common superscripts in a row are significantly different $(\mathrm{P}<0.05)$ FAME - fatty acid methyl esters; $\Sigma$ SFA- total saturated fatty acids; $\Sigma$ MUFA - total monounsaturated fatty acids; $\Sigma$ PUFA - total polyunsaturated fatty acids (excluding CLA); $\Sigma$ UFA - total unsaturated fatty acids (excluding CLA)

Table 3 shows the effects of dietary treatment on egg weights and relative proportion of yolk and albumen of eggs stored at $4{ }^{\circ} \mathrm{C}$ for 30 days. The weight of eggs from hens fed CLA was lower $(\mathrm{P}<0.05)$ compared to that of the control group group. When the eggs from CLA-fed hens were stored at $4{ }^{\circ} \mathrm{C}$ for 30 
days, the proportion $(\%)$ of yolk increased $(\mathrm{P}<0.05)$ and that of albumen decreased $(\mathrm{P}<0.05)$ compared to the control. Shell weight as a proportion of egg weight was not affected by treatment.

Table 3 Effect of including $0.5 \%$ maize oil or $0.5 \%$ conjugated linoleic acid (CLA) in the diets of hens on the relative weights of the components of their eggs when stored at $4{ }^{\circ} \mathrm{C}$ for 30 days

\begin{tabular}{lccc}
\hline & $\begin{array}{c}\text { Group A } \\
\text { (Basal diet with maize oil) }\end{array}$ & $\begin{array}{c}\text { Group B } \\
\text { (Basal diet with CLA) }\end{array}$ & s.e.m. \\
\hline Whole egg (g) & $62.3^{\mathrm{a}}$ & $59.6^{\mathrm{b}}$ & 0.9 \\
Yolk (\%) & $29.2^{\mathrm{b}}$ & $34.6^{\mathrm{a}}$ & 0.4 \\
Albumen (\%) & $60.6^{\mathrm{a}}$ & $55.1^{\mathrm{b}}$ & 0.5 \\
Shell (\%) & 10.2 & 10.3 & 0.2
\end{tabular}

\footnotetext{
$\overline{\mathrm{a}, \mathrm{b}}$ Means (30 samples/treatment) with different superscripts within a row are significantly different $(\mathrm{P}<0.05)$ s.e.m. - standard error of mean
}

Results of the egg quality evaluation are shown in Tables 4 and 5 . When eggs were stored at $4{ }^{\circ} \mathrm{C}$ for one, two or three weeks, the $\mathrm{pH}$ of egg yolk was higher and that of albumen lower in eggs from the CLA-fed hens compared those to from the control group. However, when the eggs were stored at room temperature $\left(21-24{ }^{\circ} \mathrm{C}\right)$ the $\mathrm{pH}$ of the yolk and albumen did not differ between the dietary treatments. The inclusion of CLA in the diet significantly intensified the colour indices of yolks of eggs stored for 28 days at $4{ }^{\circ} \mathrm{C}$ and 15 ${ }^{\circ} \mathrm{C}$ (Table 5). However, at the warmer temperature $\left(21-24{ }^{\circ} \mathrm{C}\right)$ dietary CLA had no effect on the colour indices in the yolk. Egg yolk from the maize oil-fed hens had higher $\mathrm{b}^{*}$ values, corresponding to a more yellow yolk, compared to the CLA group.

Table 4 Effect of including $0.5 \%$ maize oil or $0.5 \%$ conjugated linoleic acid (CLA) in the diet of hens on the $\mathrm{pH}$ (mean \pm s.e.) of the albumen and yolk of their eggs stored at $4{ }^{\circ} \mathrm{C}$ or $21-24{ }^{\circ} \mathrm{C}$ for 1,2 or 3 weeks

\begin{tabular}{ccrrrr}
\hline \multirow{2}{*}{ Weeks } & \multirow{2}{*}{ Temperature $\left({ }^{\circ} \mathrm{C}\right)$} & \multicolumn{2}{c}{ Yolk pH } & \multicolumn{2}{c}{ Albumen pH } \\
\cline { 3 - 6 } & 4 & Group A & Group B & Group A & Group B \\
\hline 1 & 4 & $5.73^{\mathrm{b}} \pm 0.02$ & $6.15^{\mathrm{a}} \pm 0.03$ & $9.09^{\mathrm{a}} \pm 0.01$ & $9.01^{\mathrm{b}} \pm 0.02$ \\
2 & 4 & $5.73^{\mathrm{b}} \pm 0.05$ & $6.89^{\mathrm{a}} \pm 0.10$ & $9.09^{\mathrm{a}} \pm 0.05$ & $8.89^{\mathrm{b}} \pm 0.06$ \\
3 & $21-24$ & $5.89^{\mathrm{b}} \pm 0.01$ & $7.22^{\mathrm{a}} \pm 0.08$ & $9.25^{\mathrm{a}} \pm 0.06$ & $8.83^{\mathrm{b}} \pm 0.08$ \\
1 & $21-24$ & $6.00 \pm 0.03$ & $6.05 \pm 0.05$ & $9.15 \pm 0.06$ & $9.10 \pm 0.06$ \\
2 & $21-24$ & $6.05 \pm 0.03$ & $6.08 \pm 0.06$ & $9.20 \pm 0.03$ & $9.24 \pm 0.05$ \\
3 & $6.28 \pm 0.04$ & $6.30 \pm 0.08$ & $9.38 \pm 0.08$ & $9.43 \pm 0.06$ \\
\hline
\end{tabular}

${ }^{\mathrm{a}, \mathrm{b}}$ Means with different superscripts within a row period differ at $\mathrm{P}<0.05$

Table 5 Effect of including $0.5 \%$ maize oil (Group A) or $0.5 \%$ conjugated linoleic acid (CLA) (Group B) in the diet of hens on the quality of their eggs stored for 28 days at different temperatures ${ }^{1}$

\begin{tabular}{cccrc}
\hline & Temperature $\left({ }^{\circ} \mathrm{C}\right)$ & L $^{*}$ value & \multicolumn{1}{c}{$\mathrm{a}^{*}$ value } & $\mathrm{b}^{*}$ value \\
\hline Group A & 4 & $71.03^{\mathrm{a}} \pm 0.31$ & $-4.88^{\mathrm{a}} \pm 0.01$ & $59.82^{\mathrm{a}} \pm 0.28$ \\
Group B & 4 & $59.08^{\mathrm{b}} \pm 0.76$ & $-3.44^{\mathrm{b}} \pm 0.11$ & $38.74^{\mathrm{b}} \pm 0.56$ \\
Group A & 15 & $70.82^{\mathrm{a}} \pm 0.36$ & $-4.87^{\mathrm{a}} \pm 0.01$ & $59.83^{\mathrm{a}} \pm 0.16$ \\
Group B & 15 & $59.99^{\mathrm{b}} \pm 0.65$ & $-3.36^{\mathrm{b}} \pm 0.05$ & $37.27^{\mathrm{b}} \pm 0.86$ \\
Group A & $21-24$ & $70.53 \pm 0.21$ & $-4.86 \pm 0.00$ & $59.55 \pm 0.32$ \\
Group B & $21-24$ & $70.66 \pm 0.12$ & $-4.84 \pm 0.02$ & $58.57 \pm 0.67$
\end{tabular}

\footnotetext{
${ }^{1} L^{*}=$ lightness (higher values indicate a lighter colour); $\mathrm{a}^{*}=$ redness (higher values indicate a more red colour); $\mathrm{b}^{*}=$ yellowness (higher values indicate a more yellow colour)

${ }^{\mathrm{a}, \mathrm{b}}$ Means were derived from three readings per sample for 10 egg yolks per group and means within columns with no common superscript differ significantly at $\mathrm{P}<0.05$
} 


\section{Discussion}

Dietary CLA was shown to influence fatty acid composition of eggs and to cause adverse effects on the quality of eggs stored at $4{ }^{\circ} \mathrm{C}$ (Aydin et al., 2001). CLA in a low-fat diet increased the level of SFA (mainly C16:0 and C18:0) and decreased the level of MUFA (mainly C16:1, n-7 and C18:1, n-9) in the egg yolk. Similarly, in the present study CLA in a low-fat diet (Group B) increased the ratio of SFA to UFA significantly. Eggs from the CLA group had 10-fold higher c-9, t-11 CLA concentrations compared to the control group. The level of t-10, c-12 CLA isomer in the eggs from the CLA-fed hens was 0.52, but it was not detectable in eggs from the Group A. When the eggs from CLA-fed laying hens were stored at $4{ }^{\circ} \mathrm{C}$, abnormal colour and $\mathrm{pH}$ changes occurred (Aydin et al., 2001). It was reported that there was an apparent migration of minerals between the yolk and albumen of eggs from hens fed a diet supplemented with $0.5 \%$ CLA when eggs were stored in $4{ }^{\circ} \mathrm{C}$ for 10 weeks. CLA eggs had higher iron, calcium and zinc concentrations and lower magnesium, sodium and chloride concentrations in albumen relative to those from laying hens fed the control diet (Aydin et al., 2001). Recently, Shang et al. (2004) showed that there was a linear increase in the levels of sodium, potassium, and magnesium of the yolk of the eggs stored at $4{ }^{\circ} \mathrm{C}$ for 28 days. Interestingly, the colour changes seen in yolk and albumen were only associated with cold storage temperatures. In the present study no abnormal colour changes were observed in the eggs from the CLA-fed laying hens when they were stored at the warmer temperatures. The actual cause for discoloration of yolk and albumen of eggs at cold temperature has yet to be determined, but is believed to be the result of yolk hardening during cold storage which consequently results in a disrupted vitelline membrane (Abo-ashour \& Edwards, 1970). A pink discoloration of the albumen may develop due to the diffusion of iron, stored in the yolk, to the albumen where it binds ovotransferin (Bandemer \& Schaible, 1946). A recent study showed that dietary CLA increased the level of C18:0 in the vitelline membrane (Watkins et al., 2003). The CLA isomer primarily involved in these adverse effects is thought to be the t-10, c-12 CLA isomer. Lee et al. (1998) showed that the t-10, c-12 CLA inhibited liver stearoyl-CoA desaturase enzyme activity, an enzyme responsible for the insertion of a double bond in C16:0 or C18:0 in the formation of C16:1(n-7) and C18:1(n9). Hence, SFA accumulates in the yolk as it is in liver or muscle. An addition of $10 \%$ olive oil prevented CLA-induced colour changes in the yolks and albumen of eggs stored at $4{ }^{\circ} \mathrm{C}$ (Aydin et al., 2001). This is probably due to decreased de novo lipogenesis in the liver of laying hens when fed a high fat diet (Naber \& Biggert, 1989). Therefore, in the presence of high fat levels in the diet, laying hens would prefer to use dietary fat instead of hepatic synthesized fat for yolk formation.

As dietary CLA has an effect on the fatty acid metabolism, it also affects the size of chicken egg. In a previous study conducted in quail, dietary CLA at the levels of $2 \%$ or $3 \%$ caused a reduction in the size of eggs compared to the control group (Aydin \& Cook, 2004). This could be due to the inhibition of stearoylCoA desaturase. As the stearoyl-CoA is inhibited, hepatic triacylglycerol secretion as VLDL declines (Legrand et al., 1997). However, when quail were fed 0.25\% CLA in low-fat diet, the size of eggs increased relative to the control group. In the present study, feeding laying hens CLA significantly reduced the egg size.

In the present study, when eggs from the CLA group were stored at $4{ }^{\circ} \mathrm{C}$ for 30 days, the percentage of yolk increased and the percentage of albumen decreased relative to the control group. Fresh eggs from the laying hens fed $0.5 \%$ CLA or eggs from the CLA group not stored at cold temperatures (or stored at room temperatures) had no increase in the relative size of egg yolk when compared to the control group (R. Aydin, unpublished data). These findings suggested that under cold room temperature some ingredients of albumen diffuse into yolk or vice versa. The increase in yolk weight of eggs from hens fed CLA was much higher than the control group (Ahn et al., 1999). A recent study showed that dietary CLA increased yolk water content linearly (Shang et al., 2004). Similarly, in the present study, when eggs from CLA-fed laying hens were stored at $4{ }^{\circ} \mathrm{C}$ for 30 days, there was a significant increase in the proportions of yolk weight and a decrease in the proportions of albumen compared to the control group. Ahn et al. (1999) showed that the yolks of eggs from CLA group had higher water content than those from the control group. This may partly explain why dietary CLA caused negative effects on the quality (i.e. colour defects and abnormal $\mathrm{pH}$ changes in yolk and albumen of eggs) of the eggs stored at $4{ }^{\circ} \mathrm{C}$. As the level of CLA was increased in the diet, yolk pH increased and albumen $\mathrm{pH}$ decreased in the eggs stored at $4{ }^{\circ} \mathrm{C}$ (Shang et al., 2004). Similar adverse effects were observed in the eggs from laying hens fed cyclopropene fatty acids (Schaible \& Bandemer, 1946). In addition to water passing into yolk from albumen, it was shown that solutes including proteins of the albumen passed into yolk so that proportion of albumen decreased (Schaible \& Bandemer, 
1946). Therefore, the increase in yolk $\mathrm{pH}$ and the decrease in albumen $\mathrm{pH}$ may be related to the migration of minerals, water and small albumen proteins. Changes in the activity of stearoyl-CoA desaturase in tissues are reflected in cell membrane phosholipids and triacylglycerol composition (Ntambi et al., 1999). It can be speculated that CLA increases SFA content of the vitelline membrane so that during cold storage the vitelline membrane is disrupted, causing leakage of minerals and water from albumen into egg yolk.

\section{Conclusion}

The present study confirmed that CLA in low-fat diets caused significant alteration in the yolk fatty acid composition and changed the quality of eggs stored at cold temperatures. This study also suggests that CLA-related colour changes observed in the yolk and albumen of eggs stored at cold temperature depend on the increase in the ratio of SFA to UFA, probably by changing the permeability of the vitelline membrane of the egg yolk.

\section{References}

Abou-ashour, A.M. \& Edwards Jr, H.M., 1970. Effect of dietary sterculia foetida oil on pink-white discoloration and fatty acid distribution in stored eggs. J. Nutr. 100, 757-766.

Ahn, D.U., Sell, J.L., Jo, C., Chamruspollert, M. \& Jeffrey, M., 1999. Effect of dietary conjugated linoleic acid on the quality characteristics of chicken eggs during refrigerated storage. Poult. Sci. 78, 922-928.

Aydin, R. \& Cook, M.E., 2004. The effect of dietary conjugated linoleic acid on egg yolk fatty acids and hatchability in Japanese quail. Poult. Sci. 83, 2016-2022.

Aydin, R., Pariza, M.W. \& Cook, M.E., 2001. Olive oil prevents the adverse effects of dietary conjugated linoleic acid on chick hatchability and egg quality. J. Nutr. 131, 800-806.

Bandemer, S.L. \& Schaible, P.J., 1946. Composition of fresh and storage eggs from hens fed cottonseed and non-cottonseed rations. IV. Spectrographic examination of the egg whites. Poult. Sci. 25, 453-455.

Chamruspollert, M. \& Sell, J.L., 1999. Transfer of dietary conjugated linoleic acid to egg yolks of chickens. Poult. Sci. 78, 1138-1150.

Chin, S.F., Liu, W., Storkson, J.M., Ha, Y.L. \& Pariza, M.W., 1992. Dietary sources of conjugated dienoic isomers of linoleic acid, a newly recognized class of anticarcinogens. J. Food Compos. Anal. 5, 185197.

Cook, M.E., Miller, C.C., Park, Y. \& Pariza, M.W., 1993. Immune modulation by altered nutrient metabolism: nutritional control of immune-induced growth depression. Poult. Sci. 72, 1301-1305.

Du, M., Ahn, D.U. \& Sell, J.L., 1999. Effect of dietary conjugated linoleic acid on the composition of egg yolk lipids. Poult. Sci. 78, 1639-1645.

Eulitz, K., Yurawecz, M.P., Sehat, N., Fritsche, J., Roach, J.A.G., Mossoba, M.M., Kramer, J.K.G., Adlof, R.O. \& Ku, Y., 1999. Preparation, separation, and confirmation of the eight geometrical cis/trans conjugated linoleic acid isomers 8, 10-through 11,13-18:2. Lipids 34, 873-877.

Folch, J., Lees, M. \& Sloane-Stanley, G.H., 1957. A simple method for the isolation and purification of total lipids from animal tissues. J. Biol. Chem. 226, 497-509.

Ha, Y.L., Storkson, J.M. \& Pariza, M.W., 1990. Inhibition of benzo(a)pyrene-induced mouse fore-stomach neoplasia by conjugated dienoic derivatives of linoleic acid. Cancer Res. 50, 1097-1101.

Ip, C., Singh, M., Thompson, H.J. \&. Scimeca, J.A., 1994. Conjugated linoleic acid suppresses mammary carcinogenesis and proliferative activity of the mammary gland in the rat. Cancer Res. 54, 1212-1215.

Lee, K.N., Kritchevsky, D. \& Pariza M.W., 1994. Conjugated linoleic acid and atherosclerosis in rabbits. Atherosclerosis 108, 19-25.

Lee, K.N., Pariza, M.W. \& Ntambi, J.M., 1998. Conjugated linoleic acid decreases hepatic stearoyl-CoA desaturase mRNA expression. Biochem. Biophys. Res. Commun. 248, 817-821.

Legrand, P., Catheline, D., Fichot, M.C. \& Lemarchal, P., 1997. Inhibiting $\Delta-9$ desaturase activity impairs triacylglycerol secretion in cultured chicken hepatocytes. J. Nutr. 127, 249-256.

Naber, E.C. \& Biggert, M.D., 1989. Patterns of lipogenesis in laying hens fed a high fat diet containing safflower oil. J. Nutr. 119, 690-695.

Nicolosi, R.J., Rogers, E.J., Kritchevski, D., Scimeca, J.A. \& Huth, P.J., 1997. Dietary conjugated linoleic acid reduces plasma lipoproteins and early aortic atherogenesis in hypercholesterolemic hamsters. Artery 22, 266-277. 
Ntambi, J.M., Choi, Y. \& Kim, Y., 1999. Regulation of stearoyl-CoA desaturase by conjugated linoleic acid. In: Advances in Conjugated Linoleic Acid. Vol. 1. Eds. Yurawecz, M.P., Mossoba, M.M., Kramer, J.K.G., Nelson, G. \& Pariza, M.W., AOCS Press, Champaign, IL. pp. 340-347.

Raes, K., Huyghebaert, G., Smet, S.D., Nollet, L., Arnouts, S. \& Demeyer, D., 2002. The deposition of conjugated linoleic acids in eggs of laying hens fed diets varying in fat level and fatty acid profile. J. Nutr. 132, 182-189.

Schaible, P.J. \& Bandemer, S.L., 1946. Composition of fresh and storage eggs from hens fed cottonseed and non-cottonseed rations. V. Cause of discoloration. Poult. Sci. 25, 456-459.

Shang, X.G., Wang, F.L., Li, D.F., Yin, J.D. \& Li, J.Y., 2004. Effects of dietary conjugated linoleic acid on the productivity of laying hens and egg quality during refrigerated storage. Poult. Sci. 83, 1688-1685.

Sun, J.H., Kang, G.H., Jeong, J.Y., Yang, H.S., Ha, Y.L., Park, G.B. \& Joo, S.T., 2003. Effect of dietary conjugated linoleic acid on lipid characteristics of egg yolk. Asian-Aust. J. Anim. Sci. 16, 1165-1170.

Watkins, B.A., Feng, S., Strom, A.K., DeVitt, A.A., Yu, L. \& Li, Y., 2003. Conjugated linoleic acids alter the fatty acid composition and physical properties of egg yolk and albumen. J. Agric. Food Chem. 51, $6870-6876$. 